\title{
A \\ B
}
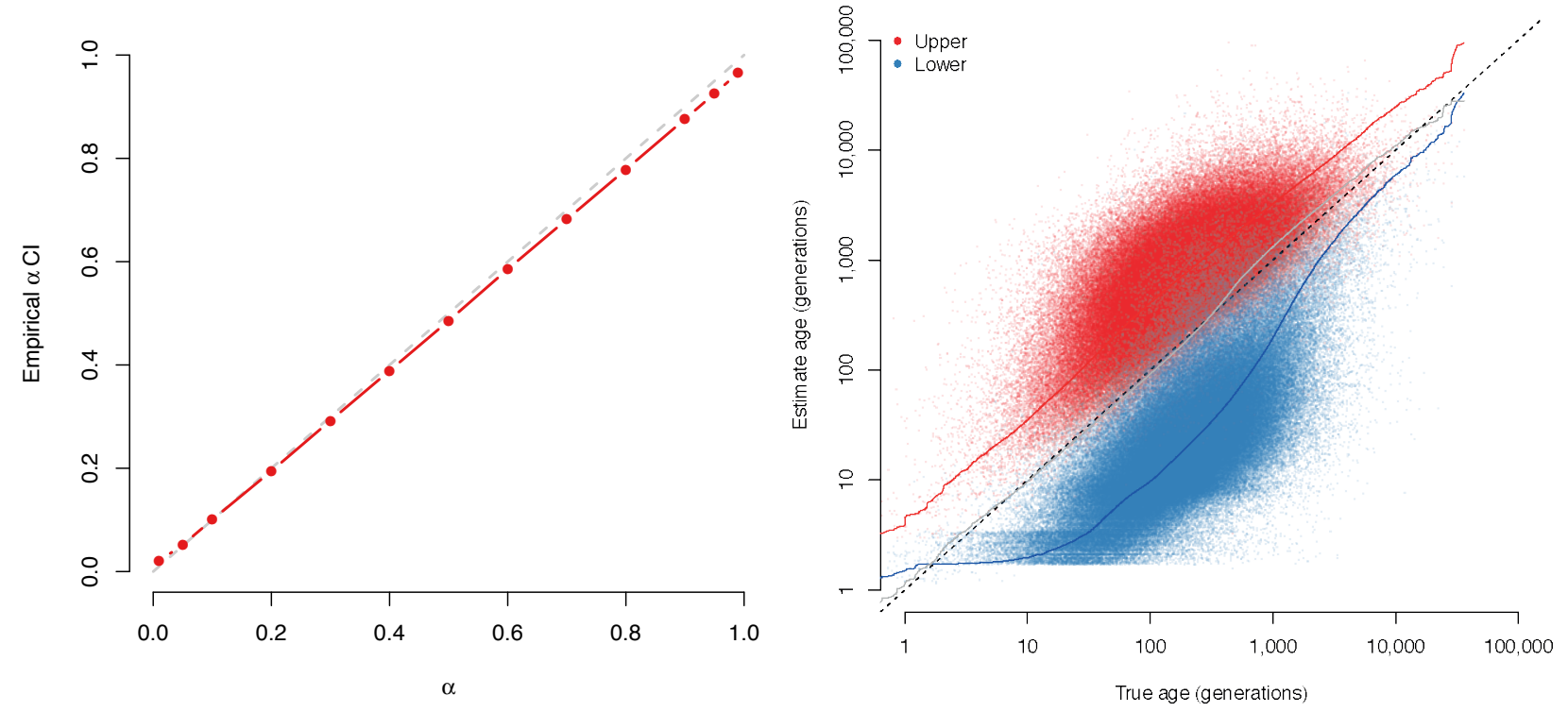